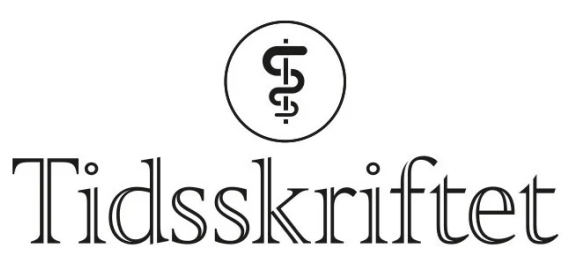

DEN NORSKE LEGEFORENING

\title{
Norsk forening for røde- og brannbiler
}

SPRÅKSPALTEN

PETTER GJERSVIK

Email: petter.gjersvik@legeforeningen.no

Tidsskriftet

\section{Rettskrivningsregler for deling av sammensatte ord bør også gjelde for spesialiteter og fagmedisinske foreninger.}

Norsk forening for fysikalsk- og rehabiliteringsmedisin (!) har foreslått å endre navnet på spesialiteten Fysikalsk medisin og rehabilitering til Fysikalsk- og rehabiliteringsmedisin. Navneendringen, som for tiden er under høring i Legeforeningen, er grundig utredet, bl.a. av en gruppe i foreningen. Gruppen gjør i sin innstilling rede for fordeler og svakheter med dagens betegnelse og ulike alternativer, bl.a. ved bruk av et skåringssystem (1). Dagens navn får 24 poeng, mens det foreslåtte navnet får 25 poeng. Her skal det gjøres vitenskapelig og med vitenskapelig presisjon! For øvrig betegner gruppen bindestreken som en tankestrek.

Gjeldende rettskrivningsregler for deling av ord innebærer at to påfølgende sammensatte ord kan deles slik: hode- og nakkeskader istedenfor hodeskader og nakkeskader. Dette forutsetter altså at det første ordet med bindestrek og siste del av det påfølgende sammensatte ordet sammen kan utgjøre et sammensatt ord. Man kan altså ikke skrive røde- og brannbiler, fordi det heter røde biler, ikke rødebiler. Man kan heller ikke skrive fysikalsk- og rehabiliteringsmedisin, fordi det heter fysikalsk medisin, ikke fysikalskmedisin.

Rettskrivningsregler endres over tid, ofte basert på feilaktig bruk over lengre tid. Det er neppe et ønske om å bidra til en sunn og naturlig språkutvikling som ligger bak foreningens forslag. Snarere vil det av mange oppfattes som slurv, mangelfull kompetanse og lavt presisjonsnivå. Dersom fagmiljøet innen fysikalsk medisin og rehabilitering mener at spesialitetsnavnet bør endres, bør andre alternativer vurderes. Snarere enn å endre navn på spesialiteten, bør foreningen vurdere å endre sitt foreningsnavn.

\section{LITTERATUR}

1. Forslag om å endre navn på spesialiteten Fysikalsk medisin og rehabilitering. www.legeforeningen.no/asset/44272/1/44272_1.pdf(5.10.2009). 
Publisert: 5. november 2009. Tidsskr Nor Legeforen. DOI: 10.4045/tidsskr.09.1193

(C) Tidsskrift for Den norske legeforening 2023. Lastet ned fra tidsskriftet.no 26. april 2023. 